\title{
IMPROVEMENT OF CAREGIVER'S ABILITY TO CARE FOR PATIENTS IN MENTARI HATI SOCIAL INSTITUTIONS TASIKMALAYA
}

\author{
${ }^{1}$ Neni Sholihat, ${ }^{2}$ Indra Gunawan, ${ }^{3}$ Nia Restiana, ${ }^{4}$ Rosy Rosnawanti, ${ }^{5}$ Saryomo \\ Program Studi S1 IImu Keperawatan Fakultas IImu Kesehatan \\ Universitas Muhammadiyah Tasikmalaya \\ JI. Tamansari KM. 2.5 PO BOX 115 Tasikmalaya \\ Corresponding Author: ${ }^{2}$ indra@umtas.ac.id
}

\begin{abstract}
Based on Riskedas data in 2013, the prevalence of mental disorders in Indonesia is about $6 \%$ of the population has emotional disorders and $1.7 \%$ of serious mental disorders. In West Java the prevalence reaches $1.6 \%$, while in Tasikmalaya City there are 171 sufferers. Mental disorders can be caused by biological, psychological and socio-cultural factors, it can also be caused by inadequate provision of patient care, especially in small towns and villages. Patients with chronic mental disorders need care management that involves various elements in the healing process, such as family, community and caregivers. The role of care giver which is very influential in the patient's healing process, they are in charge of providing emotional support and the necessities of life. The complex problems in patient care caused many of them not to be well cared for. One of the phenomena was found at the Mentari Hati Social Institusion. The caregiver's low educational background, and lack of knowledge in care, are among the factors causing the ineffective treatment provided. For this reason, a mental nursing service management program is needed which is managed in a Community Mental Health Nursing (CMHN) program which aims to empower caregivers by providing consultation and education services, and providing information on mental health principles. The purpose of this community service activity is to improve the care giver's ability to care for mental patients.
\end{abstract}

Keywords: Caregiver, Macrame, Mental Disoder, Mental Health

\section{INTRODUCTION}

Mental disorders are still a serious problem in the world. WHO (World Health Organization) revealed that in 2009, there were 24 million people suffering from schizophrenia in the world. Whereas in 2013, the number of mental patients in the world reached 450 million people and at least 1 in 4 people in the world experienced mental problems. In Indonesia, according to Riskesdas (2013), data on mental disorders clients reached 1.7 million, which means 1 to 2 people out of 1,000 population. Experiencing mental disorders not only affects individuals but also families and countries. Minimum economic loss due to mental health problems reaches 20 trillion rupiah. The data above shows that cases of mental disorders are increasing every year both in the world and in Indonesia. This mental disorder is caused by biological, psychological and socio-cultural factors. 
In addition, mental health problems also arise due to the provision of inadequate care for patients with mental disorders, especially in small cities or in rural areas (Zou, Li et al. 2013). The problem of care or caregiver for people with mental disorders in Indonesia is still very complex, there are several things expressed by the Ministry of Health of the Republic of Indonesia, the problem of resources in care, distribution of human resources that still accumulate in big cities, health facilities for treating patients with mental disorders are still very minimal, stigma and discrimination from family and caregivers, as well as the low percentage of financing for patient care with mental disorders 2 (Ernawati \& Bimo 2016), and the unequal distribution of psychologists, nurses, doctors, caregivers in health centers throughout Indonesia (Rezkisari, 2015).

Mental nursing services are provided not only for people with mental disorders but also for healthy community members according to age groups. So health services are provided in hospital service settings and in community settings. The strategies include mobilizing and empowering people to live healthily, increasing community access to quality services, improving surveillance systems, monitoring and mental health information by empowering caregivers in the community (Keliat, Panjaitan et al. 2010). Caregivers are people who are very influential in healing patients with mental disorders, they are in charge of emotional support and the necessities of life, and have risks in caring for such as raging behavior so that this treatment process affects their quality of life, this care burden is also a burden in physical form, psychic and social health caregivers of clients with severe mental disorders (Olwit, Musisi et al. 2015). Complex problems in the care of patients with mental disorders in Indonesia cause many people with serious mental disorders who are not properly cared for in the community, one of which occurs in the social orphanage of the Mentari Hati Foundation, Tasikmalaya City. Most of the caregivers at the Mentari Hati Foundation have a junior high school level education background and do not have a background knowledge about health, especially mental health. Background on caregivers and the purpose of this community service activity is to improve the caregiver's ability to care for mental patients at the Mentari Hati social institution in the City of Tasikmalaya.

\section{METHOD}

Community service activities to increase the caregiver's ability at the Mentari Hati Foundation in caring for mental patients are carried out in two activities, namely 1. delivery of material on mental disorders, signs and symptoms, and their handling to increase caregiver knowledge about mental disorders, and how to treat them, 2. The practice of making macrame was facilitated by two macrame craftsmen from the cities of Tasikmalaya and Banjar.

Delivering subject of how to taking care patient with mentalt disorder conduct by student of S1 and Ners Programme of Fakultas Ilmu Kesehatan UMTAS, and Discussion session, leads by Lecturer from same institution. Participant in this session are 19 caregiver.

Participants in the macrame-making practice are lecturers, students, caregivers and some mental patients. The aim of the practice of making macramé for caregivers and some patients with mental disorders is to improve life skills, so that it is hoped that if they are no longer in the Mentari Hati Foundation they can be economically independent. 


\section{RESULT AND DISCUSSIONS}

Community service activities to increase the caregiver's ability at the Mentari Hati Foundation in caring for mental patients are attended by 19 Caregiver and 11 Patient with Mental Disorder who lives in Mentari Hati Institution. Based on Analysis data result, it was found that the average different based on score of pre-test and post-test questioner that given to 19 caregiver about their knowledge on how to taking care mental disorder patient, it shows that their knowledge increased significantly.

How to making macramé, deliver throughout practicing step by step, in following order, that is: 1. Knowing the material that is: the main ingredient is thread or rope, the rest are additional materials such as beads, buckles, handles, rubber bands, and vas. 2. Knowing and Practicing basic knot in making macramé, that is two basic knot techniques, namely flat knots and cordon knots. From the two knots, it can be developed into various types of knots such as anchor knot, double flat, horizontal cordon, jump double flat, woven, pearl, chinese crown, and many others. And, 3. Practice making macramé by caregiver and patient with mental disorder.

Providing basic knowledge of caring for patients with mental disorders is very much needed at Mentari Hati Foundation, because most of the caregivers who care for patients there do not have a nursing education background or educated and trained health workers. They are nonexpert workers who are hired only based on the desire and sincerity to take care of and help people with mental disorders. Their very minimal knowledge can be seen from the results of the pretest given, and the change in knowledge after being given the material, seems significant, when given the posttest. Of course, education and socialization related to this still need to be carried out continuously and consistently, because information storage in the form of knowledge usually does not last long. The average caregiver, even most of them have a junior high school education background, only a few people are in high school. Why is it important to provide basic knowledge of caring for mentally ill patients to caregivers at the Mentari Hati Foundation, also because several ways of managing problems for patients with mental disorders there, actually risk worsening their condition, due to inappropriate treatment and only based on existing habits.

Introducing the craft of making macramé, aims to provide life skills that have economic value to caregivers and patients with mental disorders, as well as to provide them with positive and productive activities, while living and being cared for at Mentari Hati Foundation. Based on the results of observations during the practice of making macrame, both caregivers and patients, they enjoyed and were quite able to follow directions from the instructors, and the results can be seen that they can learn, are able to be given training, and can produce simple macrame works. Based on the results of observations during this community service activity, it is known that caregivers and even patients, are able to learn and learn things that are basic and practical, as long as the method used is right.

\section{CONCLUSION}

The provision of education and socialization related to the basic knowledge and skills of caring for patients with mental disorders needs to be carried out consistently and continuously, so that the skills and knowledge of caregivers at the Mentari Hati Foundation can continue to increase. It is hoped that the increase in the knowledge and skills of the caregivers will have a significant impact on the quality of life of patients with mental disorders being treated there. 
Providing education in the form of skills that are practical and of economic value, also needs to be done, so that caregivers and patients have alternative activities that are productive and have economic value. It is hoped that by having these skills, the quality of life of caregivers and patients can improve economically, and they have skills that can help them to live independently if they are no longer being treated.

\section{REFERENCES}

Ernawati, J. (Viva N. \& Bimo, A. (Viva N., 2016. Lima Kendala Utama Penanganan Masalah Kesehatan Jiwa. Viva News, p.Gaya Hidup, Kesehatan dan Intim. Available at: https://www.viva.co.id/gaya-hidup/kesehatan-intim/832188-limakendala-utamapenanganan-masalah-kesehatan-jiwa.

Keliat, B. A., et al. (2010). Manajemen Keperawatan Jiwa Komunitas Desa Siaga, EGC.

Olwit, C., et al. (2015). "Chronic sorrow: lived experiences of caregivers of patients diagnosed with schizophrenia in Butabika mental hospital, Kampala, Uganda." Archives of psychiatric nursing 29(1): 43-48.

Rezkisari, I. (Republika N., 2015. Penanganan Gangguan Jiwa di Indonesia Tidak Memadai. News Leasure, p.Koran, Lasure. Available at: http://www.republika.co.id/berita/gayahidup/infosehat/15/02/06/njcl6hpenanganangangguan-jiwa-di-indonesia-tidak-memadai.-

Riset Kesehatan Dasar (2013) Pedoman Pewawancara Petugas Pengumpul Data. Jakarta: Badan Litbangkes. Available at: http://www.depkes.go.id/resources/download/general/Hasil\%20Riskesdas\%202013.pdf

WHO. 2011. Mental Health atlas 2011, Mental Health Organization, ISBN 97992 41564359.

Zou, H., et al. (2013). "Self-management among Chinese people with schizophrenia and their caregivers: A qualitative study." Archives of psychiatric nursing 27(1): 42-53. 


\section{Documentations}

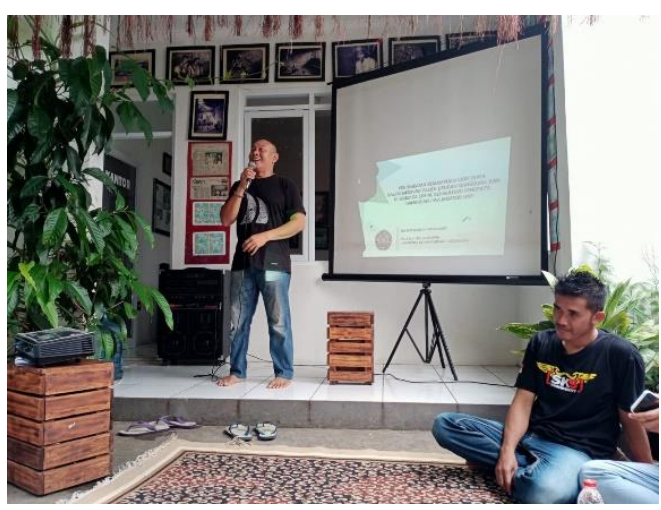

Figure1. Speech From Head Of Mentari Hati Institution

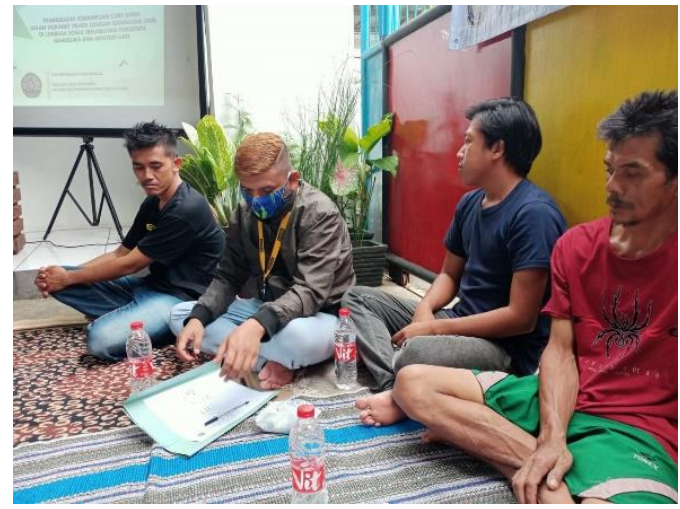

Figure 2 . Some of Male Caregiver
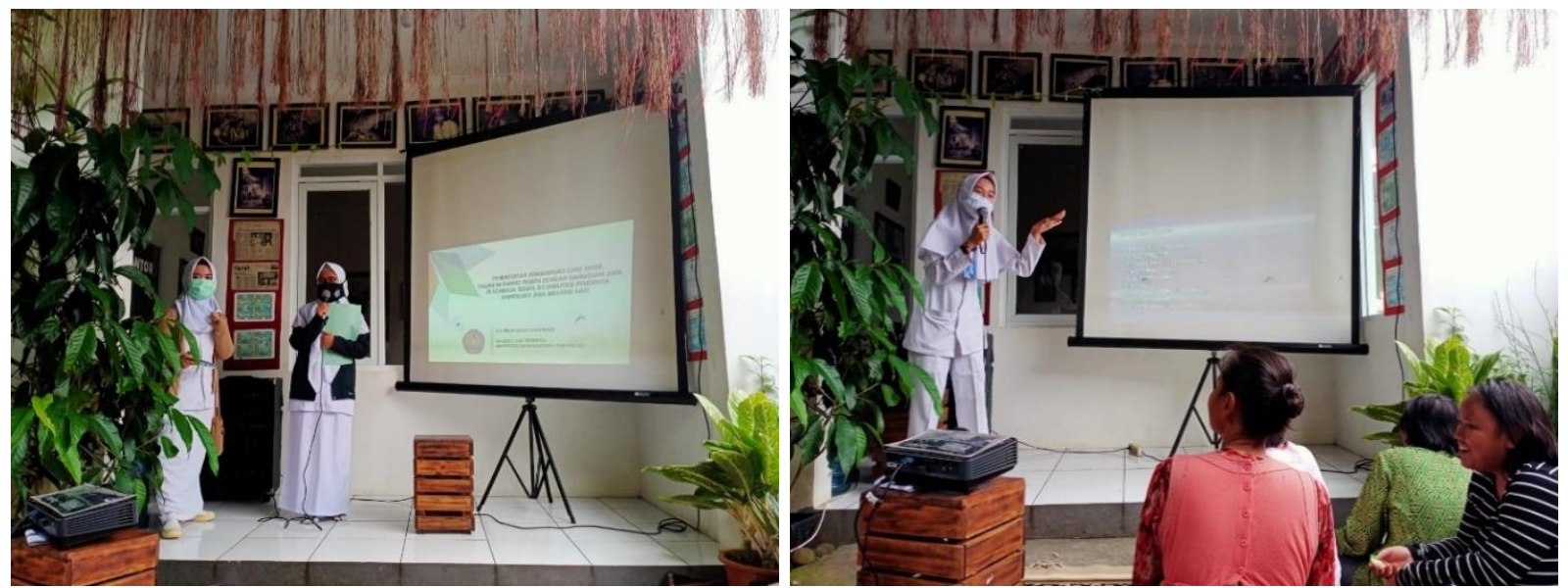

Figure 3. Delivering Subject of How to Taking Care of Mental Disorder Patient 

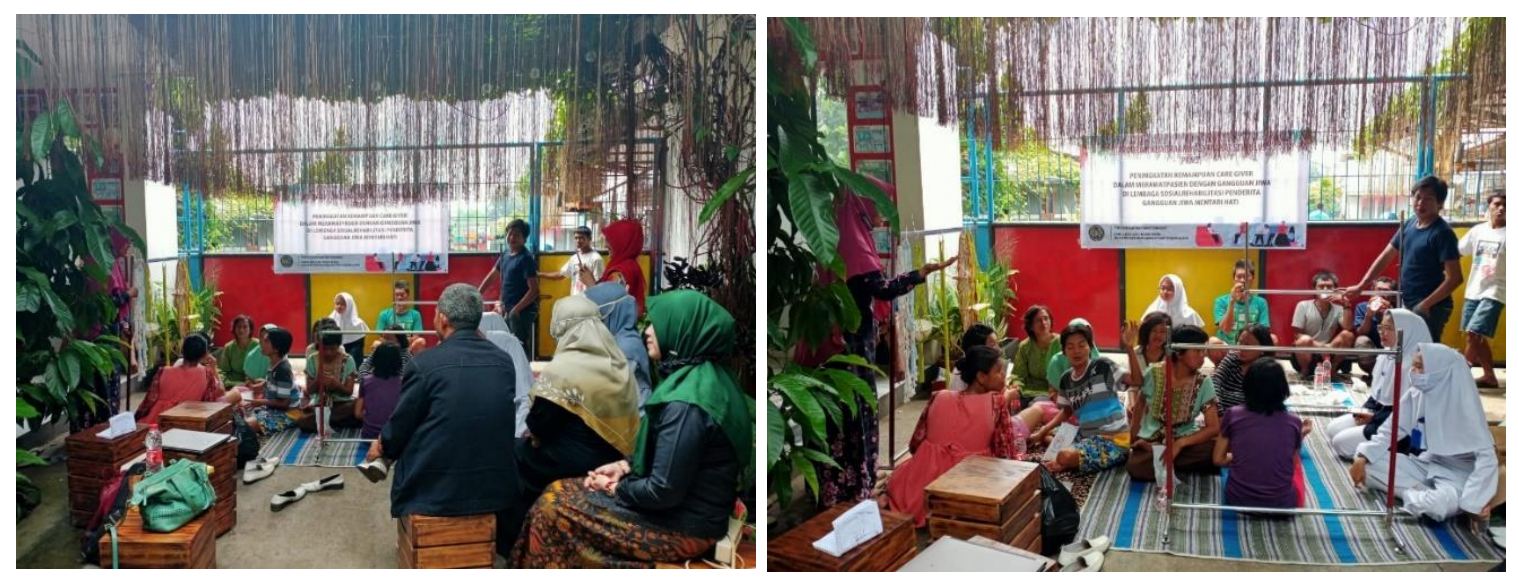

Figure 4. Delivering Subject of How to Making Macrame
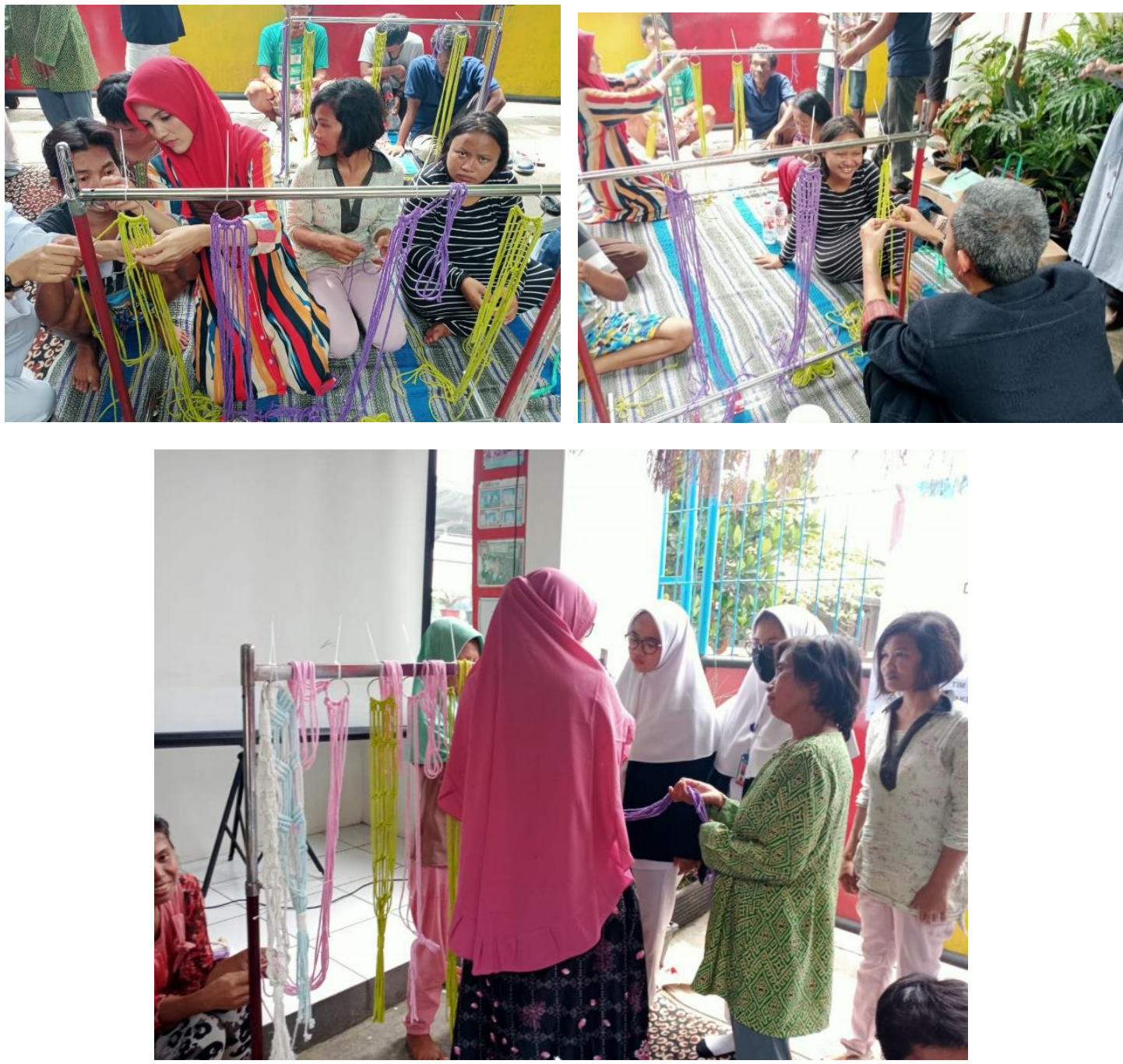

Figure 5. Practicing of How To Making Macrame 


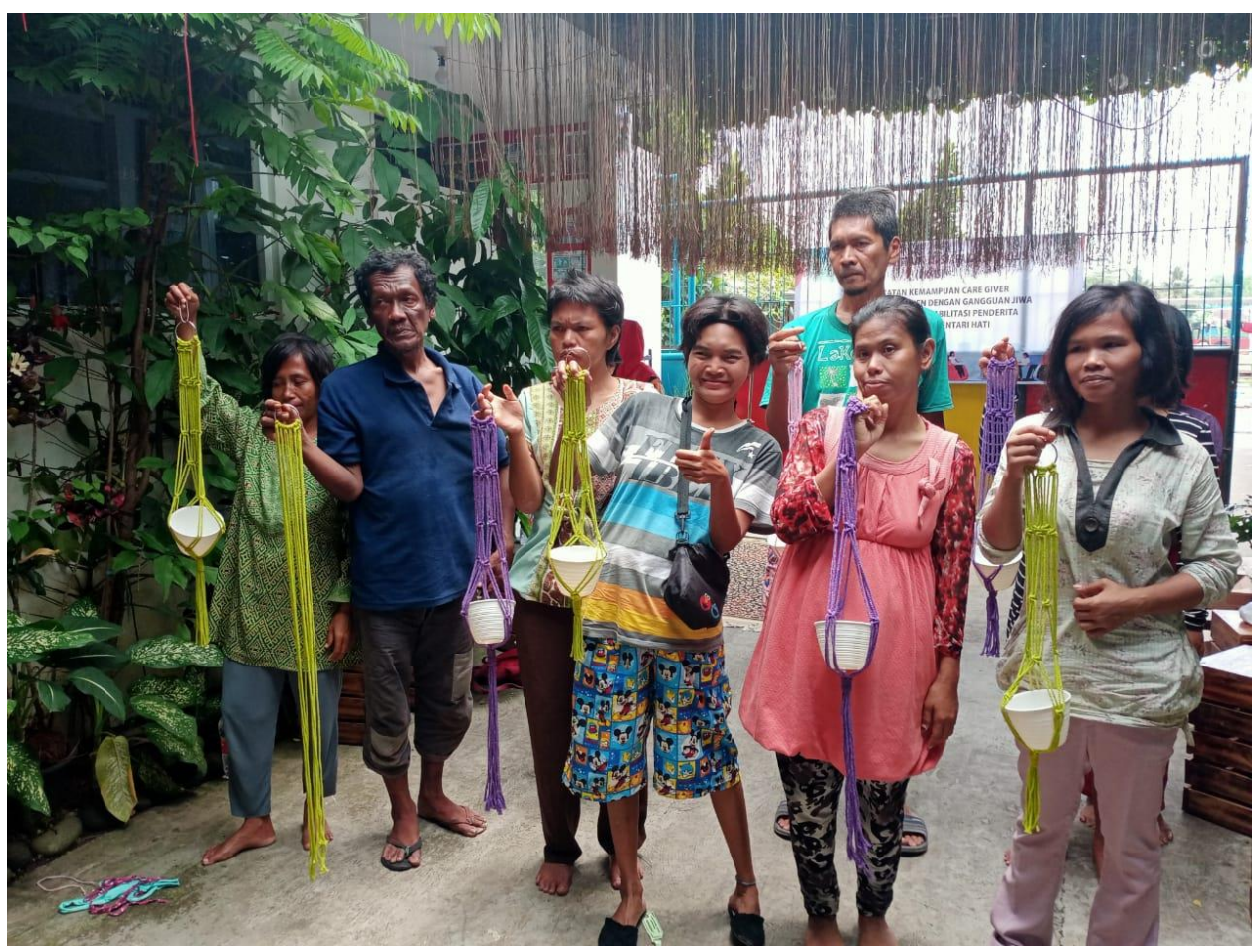

Figure 6. Patient with Mental Disorders Showing Their Macrame after Learning 